\title{
Effect of native Trichoderma isolates on the plant growth of rice (Oryza sativa L.) plant
}

\author{
Siddarth N. Rahul*¹, Kamal Khilari ${ }^{1}$, C. S. Prasad ${ }^{2}$, Ramji Singh ${ }^{1}$, Prashant Mishra ${ }^{1}$ \\ and Akash Tomar ${ }^{3}$ \\ ${ }^{1}$ Department of Plant Pathology, ${ }^{2}$ Department of Entomology, College of Agriculture, \\ ${ }^{3}$ Department of Recombination Technique, College of Biotechnology, \\ Sardar Vallabhbhai Patel University of Agriculture and Technology, Meerut 250110 (U.P.)
}

*Email: sagar4499@gmail.com

\begin{abstract}
In this study of plant growth promotion different parameter of rice viz. shoot, root length, fresh weight and dry weight of the rice plant were taken. The highest shoot length of rice plants was observed when the SVP Si 10 was applied in pots which increase the length up to $44.27 \%$ over the control. Root length of rice plants revealed that highest root length was observed in the pots sown with soil treated with isolates SVP Si $06(19.51 \%)$. The flag leaf length of rice plants shows that highest leaf length was observed in isolates SVP Si 17 (39.34 \%). In all the isolates SVPP-Si $6(39.34 \%)$ was found to be highest in increasing the fresh weight. The lowest percent increase was found in SVPP-Si 04 (2.10\%). In all the isolates SVPP-Si $03(35.00 \%)$ was found to be highest in increasing (i.e. $0.94 \mathrm{~g}$ ) the dry weight of the plant.
\end{abstract}

Keywords: Plant growth, rice, Trichoderma isolates.

Paper cited: Rahul, S.N., Khilari, K., Prasad, C.S., Singh, R., Mishra, P. and Tomar, A. (2016). Effect of native Trichoderma isolates on the plant growth of rice (Oryza sativa L.) plant. South Asian Journal of Food Technology and Environment, 2(2): 408-412.

\section{Introduction}

Rice is one of the most important food crop of India and second of the world. It feeds more than $50 \%$ of the world population. It is the staple food of most of the people of SouthEast Asia. Asia holds near about $90 \%$ to $91 \%$ of world's rice area and production respectively. Among the rice growing countries, India having the largest area under rice in the world and in case of production it is second after China. However, productivity of India is much lower $\left(13^{\text {th }}\right)$ than that of Egypt, Japan, China, and Vietnam, USA \& Indonesia and also the average productivity of the world. It contributes $42 \%$ of total food grains production and $45 \%$ of the total cereal production in the country. Each and every part of the plant have various use in society. It is also used in medicine. Rice bran oil is used as medicine as well as cooking oil (The Economic Times Agriculture 2016).
India is the second largest producer of rice after China which was 124.04 million tonne in $2015-2016$. This was $1.79 \%$ less than the previous year (The Economic Times Agriculture 2016). Trichoderma spp. recently was suggested as a Plant Growth Promoting Fungi (PGPF) due to their ability to produce siderophores, phosphate-solubilizing enzymes, and phytohormones (Doni et al., 2013).

\section{Materials and Methods}

All Trichoderma isolates were isolated previously from rhizospheric and non rhizospheric soil of different areas. The acquired sequences were submitted to the NCBI and the accession numbers were obtained as given in Table 1. Pot experiments were conducted in Completely Randomized Block Design with three replications to evaluate the performance of the most efficient isolates of Trichoderma as plant growth promoters. 
The all twenty native isolates of Trichoderma was grown on wheat grains which were soaked in ten per cent dextrose and the grains coated with Trichoderma were used after fifteen days. Trichodermaisolates were multiplied on wheat grain medium prior to experimentation. Ten seeds of cultivar 1121 were sown in $15 \mathrm{~cm}$ diameter plastic pots filled with $1 \mathrm{~kg}$ soil inoculated with 10 days old culture of the mass multiplied Trichoderma (@10 g/kg soil) at one week before sowing (Nene et al., 1981). The observations on the plant growth promotion were taken after 35 days of sowing.

\section{Results and Discussion}

In this study different parameter of rice viz. shoot, root length, fresh weight and dry weight of the rice plant were taken, results are shown in Table 2. The highest shoot length of rice plants was observed when the SVP Si 10 was applied in pots which increase the length up to $44.27 \%$ over the control. Root length of rice plants revealed that highest root length was observed in the pots sown with soil treated with isolates SVP Si 06 (19.51\%) isolates followed by SVP Si 12 (17.78\%).

Gangwar (2013) used Trichoderma isolates with two isolates of Pseudomonas which was isolated from the rice field and tested them as plant growth promotion and compared them with chemical. He found that root length $(100.15 \%)$ and shoot length (50.06\%) was recorded with FLP 88 and $T$. harzianum, respectively.

Table 1: Accession numbers obtained from NCBI after submission of sequences to the gene bank

\begin{tabular}{|c|l|l|c|}
\hline S. No. & $\begin{array}{c}\text { Trichoderma } \\
\text { isolates }\end{array}$ & \multicolumn{1}{|c|}{ NCBI identification } & $\begin{array}{c}\text { Obtained accession no. } \\
\text { form NCBI }\end{array}$ \\
\hline 1. & SVPP-Si 1 & Trichoderma longibrachiatum & KU215919 \\
\hline 2. & SVPP-Si 2 & Trichoderma asperellum & KU215913 \\
\hline 3. & SVPP-Si 3 & Trichoderma asperellum & KU215915 \\
\hline 4. & SVPP-Si 4 & Trichoderma atroviridi & KU215916 \\
\hline 5. & SVPP-Si 5 & Trichoderma asperellum & KU215914 \\
\hline 6. & SVPP-Si 6 & Hypocrea lixii & KU215917 \\
\hline 7. & SVPP-Si 7 & Trichoderma longibrachiatum & KU215918 \\
\hline 8. & SVPP-Si 8 & Trichoderma harzianum & KU215926 \\
\hline 9. & SVPP-Si 9 & Trichoderma harzianum & KU215920 \\
\hline 10. & SVPP-Si 10 & Trichoderma harzianum & KU215912 \\
\hline 11. & SVPP-Si 11 & Trichoderma asperellum & KU215922 \\
\hline 12. & SVPP-Si 12 & Trichoderma harzianum & KU215911 \\
\hline 13. & SVPP-Si 13 & Trichoderma asperellum & KU215923 \\
\hline 14. & SVPP-Si 14 & Trichoderma harzianum & KU215924 \\
\hline 15. & SVPP-Si 15 & Trichoderma asperellum & KU215910 \\
\hline 16. & SVPP-Si 16 & Trichoderma harzianum & KU215925 \\
\hline 17. & SVPP-Si 17 & Trichoderma asperellum & KU215927 \\
\hline 18. & SVPP-Si 18 & Trichoderma harzianum & KU215928 \\
\hline 19. & SVPP-Si 19 & Trichoderma lixii & \\
\hline 20. & SVPP-Si 20 & Trichoderma harzianum & \\
\hline & & & \\
\hline
\end{tabular}


The flag leaf length of rice plants shows that highest leaf length was observed in isolates SVP Si 17 (39.34\%). The minimum increase percentage was observed in SVP Si 02 $(07.62 \%)$. All the remaining isolates showed least effect on root length and it was statistically at par with check. Likewise (Mishra and Salakhe, 2011) and (Doni et al., 2014) also conducted the experiments to find out the effect of the various Trichoderma species on rice crop in which they found the effect on plant height $(70.47 \mathrm{~cm})$, tiller number (12), root length $(22.5 \mathrm{~cm})$ and root fresh weight $(15.21 \mathrm{~g})$ compared to the plants treated with other Trichoderma isolates tested was significantly higher than the control.

From Table 3, the isolates SVPP-Si 6 $(32.96$ $\%$ was found to be highest in increasing the fresh weight of the plant followed by SVPP-Si 09 (31.95\%), SVPP-Si 11 and 12 (31.11\%), SVPP-Si 03 (29.36\%) and SVPP-Si 05 (26.96\%). The lowest percent increase was found in SVPP-Si 04 $(2.10 \%)$. In all the isolates SVPP-Si 03 (35.00 $\%$ ) was found to be highest in increasing (i.e. $0.94 \mathrm{~g}$ ) the dry weight of the plant. The lowest percent increase was found in SVPP-Si 02 $(08.80 \%)$. All the native isolates significantly increase the fresh and dry weight of the plant. Many researchers like (Doni et al., 2014) and have already discussed the capacity of Trichoderma spp to promote the growth and the vigour of the plant. (Saba et al., 2012) have revealed that various isolates of Trichoderma which was T.12 and T.52 applied in substrate treatment increased aerial and root dry weight by 61.2 and $32.9 \%$, respectively.

Table 2: Effect of different native strains of Trichoderma spp. on length of root, shoot and flag leaf of the plant growth of rice plant.

\begin{tabular}{|l|c|c|c|c|c|c|}
\hline Treatment & $\begin{array}{c}\text { length of } \\
\text { shoot } \\
\text { (cm.) }\end{array}$ & $\begin{array}{c}\text { Increase } \\
\text { \% }\end{array}$ & $\begin{array}{c}\text { length of root } \\
\text { (cm.) }\end{array}$ & $\begin{array}{c}\text { Increase } \\
\text { \% }\end{array}$ & $\begin{array}{c}\text { length of flag* } \\
\text { leaf (cm.) }\end{array}$ & $\begin{array}{c}\text { Increase } \\
\text { \% }\end{array}$ \\
\hline SVPP-Si 1 & $7.97 \pm 0.06$ & 30.00 & $18.43 \pm 0.12$ & 10.47 & $15.57 \pm 0.12$ & 29.97 \\
\hline SVPP-Si 2 & $7.17 \pm 0.15$ & 23.29 & $17.07 \pm 0.12$ & 03.33 & $11.80 \pm 0.30$ & 07.62 \\
\hline SVPP-Si 3 & $7.03 \pm 0.06$ & 21.76 & $19.37 \pm 0.32$ & 14.81 & $13.70 \pm 0.20$ & 20.43 \\
\hline SVPP-Si 4 & $8.07 \pm 0.06$ & 31.84 & $17.07 \pm 0.60$ & 03.33 & $13.17 \pm 0.29$ & 17.23 \\
\hline SVPP-Si 5 & $7.93 \pm 0.06$ & 30.64 & $18.07 \pm 0.12$ & 08.68 & $14.97 \pm 0.06$ & 27.18 \\
\hline SVPP-Si 6 & $9.43 \pm 0.12$ & 41.67 & $20.50 \pm 0.44$ & 19.51 & $17.17 \pm 0.29$ & 36.51 \\
\hline SVPP-Si 7 & $8.13 \pm 0.06$ & 32.34 & $17.43 \pm 0.40$ & 05.33 & $15.30 \pm 0.17$ & 28.75 \\
\hline SVPP-Si 8 & $7.77 \pm 0.23$ & 29.21 & $18.20 \pm 0.35$ & 09.34 & $14.43 \pm 0.21$ & 24.46 \\
\hline SVPP-Si 9 & $8.03 \pm 0.06$ & 31.50 & $18.50 \pm 0.00$ & 10.81 & $13.90 \pm 0.36$ & 21.58 \\
\hline SVPP-Si 10 & $9.87 \pm 0.12$ & 44.27 & $17.63 \pm 0.23$ & 06.40 & $14.60 \pm 0.17$ & 25.34 \\
\hline SVPP-Si 11 & $8.07 \pm 0.06$ & 31.84 & $19.90 \pm 0.36$ & 17.08 & $15.63 \pm 0.15$ & 32.39 \\
\hline SVPP-Si 12 & $7.47 \pm 0.06$ & 26.37 & $20.07 \pm 0.12$ & 17.78 & $13.17 \pm 0.31$ & 17.23 \\
\hline SVPP-Si 13 & $7.60 \pm 0.00$ & 27.63 & $17.17 \pm 0.29$ & 03.90 & $13.33 \pm 0.06$ & 18.22 \\
\hline SVPP-Si 14 & $7.03 \pm 0.06$ & 21.76 & $18.07 \pm 0.12$ & 08.39 & $14.37 \pm 0.32$ & 24.14 \\
\hline SVPP-Si 15 & $7.90 \pm 0.10$ & 30.37 & $19.43 \pm 0.12$ & 15.07 & $15.27 \pm 0.29$ & 28.61 \\
\hline SVPP-Si 16 & $8.07 \pm 0.06$ & 31.84 & $17.27 \pm 0.31$ & 04.47 & $14.80 \pm 0.20$ & 26.35 \\
\hline SVPP-Si 17 & $7.07 \pm 0.06$ & 22.20 & $19.37 \pm 0.32$ & 14.81 & $17.97 \pm 0.81$ & 39.34 \\
\hline SVPP-Si 18 & $7.27 \pm 0.06$ & 24.34 & $17.40 \pm 0.35$ & 05.17 & $15.83 \pm 0.29$ & 31.14 \\
\hline SVPP-Si 19 & $7.33 \pm 0.15$ & 24.96 & $20.00 \pm 0.20$ & 17.50 & $15.50 \pm 0.40$ & 29.67 \\
\hline SVPP-Si 20 & $7.97 \pm 0.15$ & 30.00 & $19.40 \pm 0.17$ & 14.94 & $17.40 \pm 0.17$ & 37.35 \\
\hline Control & 5.50 & - & 16.50 & - & 10.90 & - \\
\hline C.D. & 0.161 & - & 0.648 & - & 0.487 & - \\
\hline
\end{tabular}

$*$ mean of three replication, \pm SD. 
Table.3. Effect of different native strains of Trichoderma spp.on the fresh and dry weight of rice plant.

\begin{tabular}{|l|c|c|c|c|}
\hline Treatment & $\begin{array}{c}\text { Fresh weight of } \\
\text { plant (gm.) }\end{array}$ & Increase \% & $\begin{array}{c}\text { Dry weight of } \\
\text { plant(gm.) }\end{array}$ & Increase \% \\
\hline SVPP-Si 1 & $3.27 \pm 0.40$ & 14.67 & $0.74 \pm 0.04$ & 17.56 \\
\hline SVPP-Si 2 & $3.26 \pm 0.13$ & 14.41 & $0.67 \pm 0.02$ & 08.80 \\
\hline SVPP-Si 3 & $3.95 \pm 0.15$ & 29.36 & $0.94 \pm 0.03$ & 35.00 \\
\hline SVPP-Si 4 & $2.85 \pm 0.08$ & 02.10 & $0.70 \pm 0.09$ & 12.85 \\
\hline SVPP-Si 5 & $3.82 \pm 0.08$ & 26.96 & $0.84 \pm 0.04$ & 27.38 \\
\hline SVPP-Si 6 & $4.14 \pm 0.06$ & 32.96 & $0.90 \pm 0.01$ & 32.22 \\
\hline SVPP-Si 7 & $2.89 \pm 0.07$ & 03.46 & $0.71 \pm 0.01$ & 14.88 \\
\hline SVPP-Si 8 & $3.61 \pm 0.51$ & 22.71 & $0.72 \pm 0.01$ & 15.27 \\
\hline SVPP-Si 9 & $4.10 \pm 0.09$ & 31.95 & $0.90 \pm 0.01$ & 32.22 \\
\hline SVPP-Si 10 & $3.65 \pm 0.06$ & 23.56 & $0.74 \pm 0.04$ & 14.80 \\
\hline SVPP-Si 11 & $4.05 \pm 0.12$ & 31.11 & $0.85 \pm 0.03$ & 15.27 \\
\hline SVPP-Si 12 & $4.05 \pm 0.06$ & 31.11 & $0.87 \pm 0.04$ & 29.88 \\
\hline SVPP-Si 13 & $3.65 \pm 0.06$ & 23.56 & $0.76 \pm 0.03$ & 19.73 \\
\hline SVPP-Si 14 & $2.93 \pm 0.03$ & 04.77 & $0.68 \pm 0.01$ & 11.76 \\
\hline SVPP-Si 15 & $3.17 \pm 0.15$ & 04.98 & $0.79 \pm 0.02$ & 22.78 \\
\hline SVPP-Si 16 & $3.08 \pm 0.12$ & 09.41 & $0.67 \pm 0.02$ & 08.95 \\
\hline SVPP-Si 17 & $3.71 \pm 0.12$ & 24.29 & $0.74 \pm 0.02$ & 17.56 \\
\hline SVPP-Si 18 & $3.04 \pm 0.12$ & 08.23 & $0.78 \pm 0.01$ & 20.11 \\
\hline SVPP-Si 19 & $3.64 \pm 0.24$ & 23.35 & $0.83 \pm 0.07$ & 26.50 \\
\hline SVPP-Si 20 & $3.70 \pm 0.02$ & 24.59 & $0.81 \pm 0.01$ & 24.69 \\
\hline Control & 2.79 & - & 0.611 & - \\
\hline C.D. & $\mathbf{0 . 2 8 7}$ & - & $\mathbf{0 . 0 5 6}$ & - \\
\hline Pot based st & & & & \\
\hline
\end{tabular}

*Pot based study, \pm Standard Deviation

\section{Conclusion}

The benefit of Trichoderma spp. in improving plant growth can be obtained through several mechanisms which include mycoparasitism, antibiosis, degradation of toxins, inactivation of pathogenic enzymatic pathways, resistance to pathogens, enhanced nutrient uptake, solubilization, sequestration of inorganic nutrients, and enhanced root hair development. In the present investigation effect on the flag leaf length of rice plants shows that highest leaf length was observed in isolates SVP $\mathrm{Si} 17$ (39.34\%). In all the isolates SVPP-Si $6(32.96 \%)$ was found to be highest in increasing the fresh weight. In all the isolates SVPP-Si 03 (35.00\%) was found to be highest in increasing (i.e. $0.94 \mathrm{~g}$ ) dry weight of the plant.

\section{References}

1. Doni, F., Al-Shorgani, N.K.N., Tibin, E.M.M., Abuelhassan, N.N., Anizan, I., CheRadziah, C.M.Z. and Wan Mohtar, W.Y. (2013). Microbial involvement in growth of paddy. Current Research Journal of Biological Science, 5(6): 285-290.

2. Doni, F., Anizan, I., CheRadziah, C.M.Z., Salman, A.H., Rodzihan, M.H., Wan Mohtar, W.Y. (2014). Enhancement of rice seed germination and vigour by Trichoderma spp. Research Journal on Applied Science and Engineering Technology, 7(21): 4547-4552.

3. Doni, F., Isahak, A., Zain, C.R.C.M. and Yusoff, W.M.W. (2014). Physiological and growth response of rice plants (Oryza sativa L.) to Trichoderma spp. 
inoculants. http://www.ambexpress.com/content/4/1/45.

4. Gangwar, G.P. (2013). Growth promotion of rice seedlings by fungal and bacterial bio-agents effective against bacterial leaf blight of rice. Journal of Applied and Natural Science, 5(2): 430434.

5. Mishra, A. and Salokhe, V.M. (2011). Rice growth and physiological responses to SRI water management and implications for crop productivity. Paddy Water Environment, 9: 41-52. doi: 10.1007/s10333-010-0240-4.

6. Nene, Y.L., Haware, M.P. and Reddy, M.V. (1981). Chickpea Diseases: Resistance Screening Techniques. Information Bulletins No. 10. ICRISAT, Patancheru, A.P., India, pp. 1-10

7. Saba, H.D.V., Manisha, M., Prashant, K.S., Farham, H. and Tauseff, A. (2012). Trichoderma - a promising plant growth stimulator and Biocontrol agent. Mycosphere, doi:10.5943 / mycosphere / $3 / 4 / 14$.

8. Times of India (2016). The Economic Times Agriculture. Internet source. 